\title{
Morpho-molecular genetic assessment of five Quinoa (Chenopodium quinoa Willd) genotypes cultured under Egyptian climate conditions
}

\author{
Aya Abdalla ${ }^{1}$, H. Sherif ${ }^{2}$, I. Elshawaf ${ }^{3}$, T. Salim ${ }^{4}$, and A. Shams ${ }^{5}$ \\ ${ }^{1}$ B.Sc. Agricultural Science (Genetic), Fac. Agri., Benha Univ, ${ }^{2,3}$ Professor of Genetics, Department of Genetics \\ and Genetic Engineering, Fac. Agri., Benha University, ${ }^{4}$ Doctor of Genetics, Fac. Agri., Benha \\ University, ${ }^{5}$ Researcher at Crop Intensification Research Department in Agricultural Research Center. \\ Corresponding author: osha2053@yahoo.com.
}

\begin{abstract}
Four introduced quinoa genotypes, moreover one recently domesticated variety were utilized as a part of the present study. Domesticated variety acquired the name Giza1, while the other introduced genotypes named Q18, Q21, Q22, and Q29. First genotype obtained from Denmark, the other genotypes introduced from Chile. All genotypes cultured in a randomized complete block design with four replications in two locations Moshtohor in Qalyubiya governorate, and Nabtit at Sharqia governorate. This investigation included six imperative attributes influencing the yield, 1) plant tallness $(\mathrm{cm}), 2$ ) number of branches/plant, 3) primary head weight/plant $(\mathrm{g}), 4)$ weight of the 1000-grain (g), 5) grain yield weight /plant (g), 6) yield weight $(\mathrm{kg} / \mathrm{ha}), 7)$ life cycle length (day).Statistical analysis of the two characters branches number / plant, and life cycle length detects no significant differences between all genotypes. At the other side plant height with Q29 showing the lowest height $111.63 \mathrm{~cm}$. Genotype Q18 was significantly the tallest (119.75).Main head weight gave lowest reading with the variety Giza1 (16 gram). The greatest value obtained from the genotype Q22.Fourth trait was grain yield per plant. Lowest means were obtained from the two genotypes Giza1 and Q18 with 13.12 and 19.75 gram respectively, while the two genotypes Q22, and Q29 record best results with means 19.38, and 19.5 consequently. Regarding 1000-grain weight the variety Giza1 gave also weakest reading 3.21 gram. At the other hand genotype Q22 gave superior 1000-grain weight 3.49 gram. Grain yield/ ha show weakest results with Q21, Giza1, and Q22 with means 2.14, 2.16, and 2.39 ton / ha respectively. Genotype Q29 gave 3.32 ton grain yield / ha. Total protein extracted from the five genotypes, to study the optimum conditions for preparing the protein isolate of quinoa seeds and investigates the physicochemical and functional properties of the isolated protein to assess the potential use of quinoa protein isolate in food applications and manufacturing. The protein isolate of quinoa was obtained by protein solubility at alkaline $\mathrm{pH}$ value, followed by precipitation at an acidic $\mathrm{pH}$ values $(2,4$, and 6). SDS-PAGE showed protein bands with $177,8 \mathrm{KDa}$ and $34,91 \mathrm{KDa}$ potentially corresponding to cheno protein in some extraction pHs. Quinoa protein had reasonable concentrations of essential amino acids (except tryptophan) with a high level of lysine $(17.13 \%)$. A sharp maximum solubility was observed at the $\mathrm{pH}$ value (4.0), and the maximum value was observed at the alkaline. Quinoa protein showed a high In Vitro digestibility.
\end{abstract}

Keywords: Chenopodium quinoa, genetic assessment, SDS-PAGE.

\section{Introduction}

Quinoa (Chenopodium quinoa Willd) is a pseudograin and is one of the 250 plant species incorporated into the genus Chenopodium (Amaranthaceae), generally known as 'goosefoot' genus(Giusti 1970). The genus contains herbaceous, suffrutescent, and arborescent perennials, albeit most species are colonizing annuals(Fuentes et al. 2012). Quinoa alongside some verdant chenopods (C. collection and C. giganteum) will be essential to the nourishment security of minor ranchers as they demonstrate adjustment to numerous abiotic and biotic stresses and their capacity to develop with least supplies (Bhargava and Srivastava 2013). It is an allotetraploid $(2 \mathrm{n}=36)$ annual, self-fertile crop as it indicates disomic inheritance for a large portion of the traits (Maughan et al. 2004).

The little seed of quinoa contains abalanced composition of carbohydrates, fat, and protein (Chauhanet al.1992). Additionally, the protein isn't just higher $(7.5-22.1 \%)$ than stable grains but on the other hand is made out of 9 amino acids being rich in lysine, threonine, and methionine (Escuredo et al. 2014). The protein is of superb containing substantially higher substance of lysine than oats and even drain and being without gluten makes it appropriate for celiac(Stikic et al. 2012). Quinoa starch is available as little granules of around 1- 1.5 $\mu \mathrm{m}$ in breadth and a normal molar mass of $11.3 \times 106$ $\mathrm{g} / \mathrm{mol}$ (Lindeboom 2005). The little granules and high consistency of quinoa starch make it valuable for particular modern applications, for example, tidying starches in makeup and elastic tire shape discharge specialists and as biodegradable fillers in lowthickness polyethylene (LDPE) films(Ahamed et al. 1996b). Quinoa starch because of its interesting mechanical properties can be used in the make of bearer sacks where elasticity is essential. As a result of the freeze- defrost dependability and protection from retro-degree the quinoa starch glue is extremely reasonable in the arrangement of solidified and emulsion-type nourishment items (Nisimba et al. 2008). It is likewise rich in fundamental vitamins and minerals, iron, and calcium. Quinoa has been selected by FAO (2014) as one of the crops destined to offer 
food security in the 21 st century, because the quinoa plants are tolerant to salinity and drought stress, and can grow on marginal regions (Jacobsen et al., 2003).

Objectives of the present study were to:

1.Quantify the genetic variability and diversity available in Quinoa genotypes in Egypt.

2. Statistically, analyses the data through clustering algorithm and principal component analysis.

3. Report degree of diversity and differentiation among Quinoa genotypes in Egypt, assessed using SDS-PAGE .

\section{Materials and Methods}

\section{Sample Preparation}

Five genetic structures of quinoa seeds (Chenopodium quinoa) were obtained from the

Egyptian Agriculture Research Center, Cairo, Egypt.

\section{Flour preparation}

Whole seeds were washed with cold water 4-5 times or untilthere was no foam to remove saponins, then oven-dried at $45 \pm 1$ _C for $24 \mathrm{~h}$ or until being dry. The whole seeds wereground into flour using Miller (Proctor Silex model E160, UPC) with a sixty-mesh screen (Abugoch et al., 2008).

\section{Preparation of protein isolate}

Quinoa protein isolates were obtained using isoelectric precipitation method at different pHs,(PH2,PH4,PH6,5\% Nacl). Samples was grinded by liquid nitrogen using mortar \&pestle and transferred the samples to Eppendorf tubes then ground with $1.5 \mathrm{ml}$ distilled water, and the $\mathrm{pH}$ was adjusted to $(2,4$ and 6$)$ using $0.1 \mathrm{~N} \mathrm{NaOH}$ and $0.1 \mathrm{~N}$ $\mathrm{HCl}$. Then put the suspension in a water bath for $3 \mathrm{~h}$ at 37 C, then centrifuged for $15 \mathrm{~min}$ at $10000 \mathrm{rpm}$ at 4Oc. the supernatant was stirredfor further analysis.

\section{Biochemical genetic studies.}

Determination of total proteins by SDS-PAGE separation.Sodium dodecyl sulfate polyacrylamide gel electrophoresis(SDS-PAGE) was performed according to method of Laemmli (1970), to discriminate and finger Quinoa flour, with $5 \%$ of stacking gel and $12 \%$ of separating gel. Samples (20 11) were prepared from $500 \mathrm{ll}$ protein solution were added to $1 \mathrm{ml}$

buffer (distilled water, $0.5 \mathrm{M}$ Tri- $\mathrm{HCl} \mathrm{pH} 6.8$, glycerol, $10 \%$ SDS, $1 \%$ bromophenol blue and bmercaptoethanol) and heated at 98 _C for $10 \mathrm{~min}$, then applied to the sample wells.( Elsohaimy, S.A et al., 2015). The standard protein marker (broad range molecular weight, Bio-Rad Hercules, USA), which contained $(245,180,135,100,75,63,48,35$ and 25 $\mathrm{KDa}$ ) was used as molecular weight standard. Electrophoretic migration was monitored at constant current (14 mA/gel) for 1.5-2 h. Gel was fixed with fixing solution (water/methanol/acetic acid 700:200:100 ml) for $30 \mathrm{~min}$ and then stained with Coomassie Brilliant Blue R-250 for $1 \mathrm{~h}$. The stained gel was destained by frequently changing the fixing solution until the excess stain disappeared.

\section{Statistical analysis}

The data were analyzed using MStat version Software. One-Way-ANOVA analysis

with p 60.05 was performed to identify significant differences among all studies parameters. All experiments carried out in triplicates.

\section{RESULTS}

The mean values for morphological and seed yield traits are presented in table 1. Performance of quinoa varied greatly between genotypes in Egyptian conditions plant height ranged from 111.63 to 119.75 $\mathrm{cm}$, with Q29 showing the lowest height 111.63 the three genotypes Q22, Q21, and Giza1 gave slightly higher records without significant difference. At the other hand genotype Q18 was significantly the tallest (119.75). Second morphological character was branches number per plant. Means of this character ranged from 20.38 in genotype Q22 to 21.63 in the two genotypes Giza1, and Q21. According to the statistical analysis, we do not notice any significant differences in the number of branches between all genotypes.

Concerning weight of the main head, significant differences noticed between means of the five genotypes. Main head weight gave lowest reading with the variety Gizal (16 gram). Genotype Q18 record higher weight 18.125. Genotypes Q21 and Q29 was significantly higher than the variety with 19.38 and 20 gram. The greatest value for weight of the main head obtained from the genotype Q22.

Fourth studied trait was grain yield per plant. Lowest means were obtained from the two genotypes Giza1 and Q18 with 13.12 and 19.75 gram respectively, followed by Q21 with 16.75 .

Remained two genotypes Q22, and Q29 record best results with means 19.38 , and 19.5 consequently.

Regarding 1000-grain weight the variety Giza1 gave also weakest reading 3.21 gram, followed by the two genotypes Q18, and Q29 with 3.25, and 3.29 respectively. Genotype Q21 gave higher reading with mean 3.37. Q22 gave superior 1000-grain weight 3.49 gram.

Grain yield/ ha show weakest results with Q21, Giza1, and Q22 with means 2.14, 2.16, and 2.39 ton / ha respectively. Genotype Q18 was significantly higher 2.98. Genotype Q29 seems the best one as it gave 3.32 ton grain yield / ha

Regarding the character life cycle length all the five genotypes gave the same mean of life cycle 131.5 day. 
Table 1. Plant height (centimeter), No of branches/plant, weight of main head (grams), grain yield/ plant(grams), 1000- grain weight (grams), ), grain yield/ hect., and life cycle (day) for the four genotypes 1/ Plant height (centimeter)

\begin{tabular}{|c|c|c|c|c|c|}
\hline GENOTPE & Giza1 & Q18 & Q21 & Q22 & Q29 \\
\hline Mean & 114.625 & $119.75 b$ & $113.5 \mathrm{a}$ & $112.625 \mathrm{a}$ & $111.625 \mathrm{a}$ \\
\hline \multicolumn{6}{|c|}{ LSD 0.05 :Between Genotypes $=3.58$} \\
\hline \multicolumn{6}{|c|}{ 2/ No of branches/plant } \\
\hline GE NOT Y P E & Giza1 & Q18 & Q21 & $\mathbf{Q 2 2}$ & Q29 \\
\hline Mean & 21.625 & 21.375 & 21.625 & 20.375 & 20.875 \\
\hline \multicolumn{6}{|c|}{ LSD 0.05 :Between Genotypes (G) not significant (NS) } \\
\hline \multicolumn{6}{|c|}{ 3/ Weight of main head/g } \\
\hline GE NOT Y P E & Giza1 & Q18 & Q21 & Q22 & Q29 \\
\hline Mean & $16.0 \mathrm{a}$ & $18.125 \mathrm{ab}$ & $19.375 b c$ & $20.75 \mathrm{c}$ & $20.0 \mathrm{bc}$ \\
\hline \multicolumn{6}{|c|}{ LSD 0.05 :Between Genotypes $=2.5$} \\
\hline \multicolumn{6}{|c|}{ 4/ Grain yield/ plant } \\
\hline G E N O T Y P E & Giza1 & Q18 & Q21 & Q22 & Q29 \\
\hline Mean & $13.125 \mathrm{a}$ & $19.75 \mathrm{a}$ & $16.75 \mathrm{ab}$ & $19.375 b$ & $19.5 b$ \\
\hline \multicolumn{6}{|c|}{ LSD 0.05 :Between Genotypes $(\mathbf{G})=3.94$} \\
\hline \multicolumn{6}{|c|}{ 5/ 1000- grain weight } \\
\hline G E N O T Y P E & Giza1 & Q18 & Q21 & Q22 & Q29 \\
\hline G. Mean & $3.212 \mathrm{a}$ & $3.25 \mathrm{ab}$ & $3.37 \mathrm{bc}$ & $3.486 \mathrm{c}$ & $3.295 \mathrm{ab}$ \\
\hline \multicolumn{6}{|c|}{ LSD 0.05 :Between Genotypes $(\mathbf{G})=0.13$} \\
\hline \multicolumn{6}{|l|}{ 6/ Grain yield/ hect. } \\
\hline GE NOT Y P E & Giza1 & Q18 & Q21 & Q22 & Q29 \\
\hline G. Mean & $2.155 \mathrm{a}$ & $2.98 \mathrm{~b}$ & $2.144 a$ & $2.389 \mathrm{a}$ & $3.317 \mathrm{~b}$ \\
\hline \multicolumn{6}{|c|}{ LSD 0.05 :Between Genotypes $(G)=0.47$} \\
\hline \multicolumn{6}{|l|}{ 7/ Life cycle (day) } \\
\hline GE NOT Y P E & Giza1 & Q18 & Q21 & Q22 & Q29 \\
\hline G. Mean & 131.5 & 131.5 & 131.5 & 131.5 & 131.5 \\
\hline
\end{tabular}

LSD 0.05 :Between Genotypes (G) not significant (NS)

Molecular Characterization of Proteins in Quinoa Flours by SDS- PAGE Results:

Analysis of the electrophoretic patterns for quinoa proteins extracted in buffers with different $\mathrm{PH}$ values indicates in (Fig. 1). 
$\begin{array}{llllllllllllllllllllll}M & 1 & 2 & 3 & 4 & 5 & 6 & 7 & 8 & 9 & 10 & 11 & 12 & 13 & 14 & 15 & 16 & 17 & 18 & 19 & 20\end{array}$

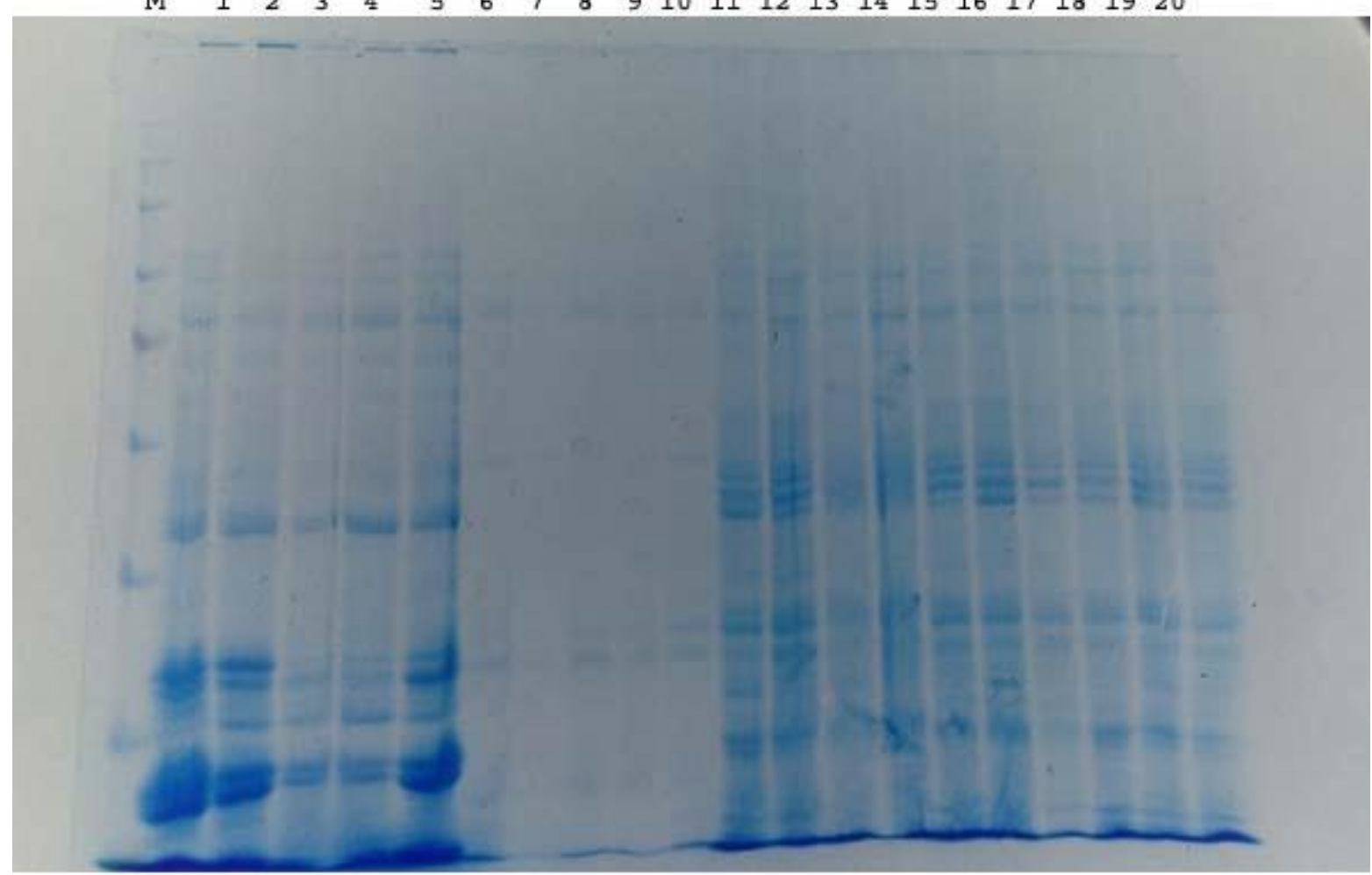

Fig. 1. Fixed porosity SDS-PAGE of quinoa proteins soluble in differentbuffer systems. Lanes: 1,2,3,4 and5 in buffer $(5 \% \mathrm{NaCl}) ; 6,7,8,9$ and10 in PH2 buffer; 11,12,13,14 and 15 in PH4 buffer: 16,17,18,19 and 20 in PH6 buffer .fixed volume $(10 \square \mathrm{L})$ of a protein solution was prepared and loaded ineach sample lane. M, molecular weight markers with MW $(245,180,135,100,75,63,48,35$ and $25 \mathrm{KDa})$.

The effect of adding $5 \% \mathrm{NaCl}$ on the protein extractability.

Total soluble proteins in all five samples (Giza1, Q18, Q21, Q22, and Q29) were resolved in 10 bands ranging from $177.8 \mathrm{KDa}$ to $35.4 \mathrm{KDa}$. All five samples showed eight polymorphic bands at molecular weights (177.8 ,144.9,137.2,114.7,40.8,37.4,36.4 and $35.4 \mathrm{kDa})$, and two bands were monomorphic at molecular weights(
60.9 and 44.2KDa) were appeared in all genotype. Two bands (MW = 177.8 and 137.2) was identified only in one genotype Giza1. On the other hand, there were two bands not found only in the Sam genotype Giza1 theband (MW=40.8 and 37.4).Moreover, the band $(\mathrm{MW}=114.7)$ was disappeared only in one genotype Q18and also the band $(\mathrm{MW}=35.4)$ was disappeared only in one genotype Q29.

Table 2. Similarity analysis for the protein profiles of all genotype extracted in $5 \% \mathrm{Nacl}$ buffer.

\begin{tabular}{llllll}
\hline \multicolumn{2}{l}{ Similarity Matrix computed with Jaccard coefficient } & & & \\
\hline & Giza1 & Q18 & Q21 & Q22 & Q29 \\
\hline Giza1 & 1 & 0.333 & 0.444 & 0.556 & 0.4 \\
\hline Q18 & 1 & 0.833 & 0.5 & 0.5 \\
\hline Q21 & & 0.444 & 0.625 & 1 \\
\hline Q22 & & & 0.4 & 1 \\
\hline Q29 & & & & 1 \\
\hline
\end{tabular}

The dendrogram obtained from protein profiles grouped the five samples into two major clusters A \& $\mathrm{B}$ (Figure 2) containing two samples in cluster A (Q22 and Giza). Three samples (Q29,Q21 and Q18) in cluster B. Cluster B was sub-divided into two subclusters B1\&B2. Sub cluster B1 consisted of the sample Q29. Sub cluster B2 consisted of two samples (Q21 and Q18). 


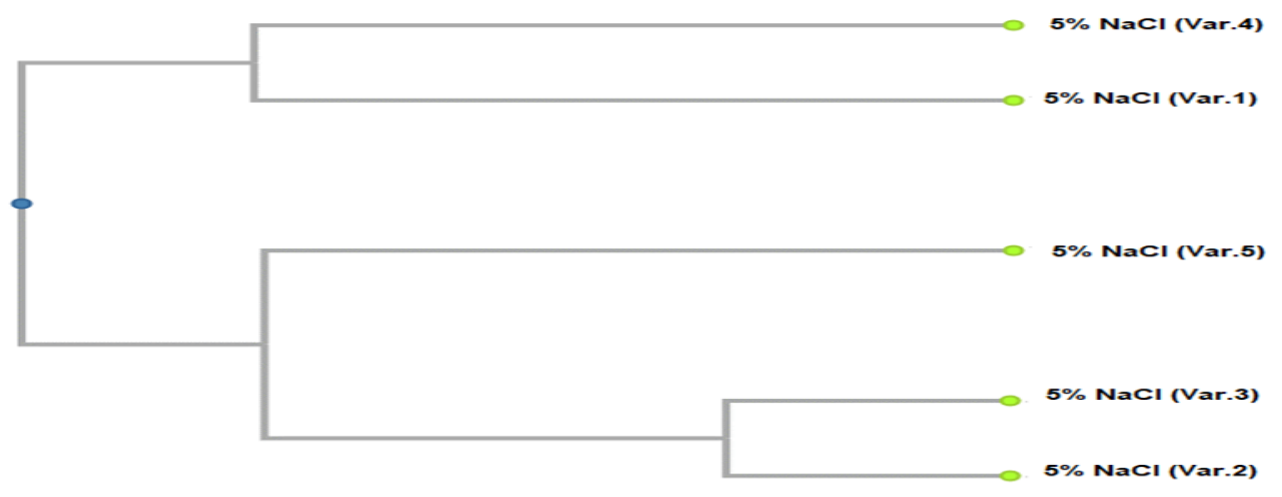

Fig 2. DendrogramShowing cluster analysis dissimilarity estimates from protein profiles of all genotype extracted in 5\% Nacl buffer.Var.1= Giza1, Var.2=Q18, Var.3=Q21, Var.4=Q22, Var.5=Q29.

The effect of adding Protein Extraction Buffer pH2.

Total soluble proteins in all five samples (Giza1, Q18, Q21, Q22, and Q29) were resolved in 10 bands ranging from $145.5 \mathrm{KDa}$ to $35.8 \mathrm{KDa}$. All bands were polymorphic bands at molecular weights (145.5 ,123.4,115.5,88.9,73.1,61.7,47.5,44.06,37.5 and 35.8 $\mathrm{kDa}$ ). The genotype Gizal showed eight bands at different molecular weights, four bands (MW $=145.5$,
$115.5,88.9$ and 37.5$)$ was identified only in genotype Giza1 and the other four bands were polymorphic bands. On the other hand, there were two bands appeared only in the genotype Q18 the band (MW=123.4 and 47.5KDa). Moreover, the genotype Q21 showed only one band $(\mathrm{MW}=61.7)$, also genotype Q29 had only one band (MW=73.1), but the genotype Q22 hadn't any bands.

Table 3. Similarity analysis for the protein profiles of all genotype extracted in $\mathrm{PH} 2$ buffer.

\begin{tabular}{|c|c|c|c|c|c|}
\hline \multicolumn{6}{|c|}{ Similarity Matrix computed with Jaccard coefficient } \\
\hline & Giza1 & Q18 & Q21 & Q22 & Q29 \\
\hline Giza1 & 1 & 0.25 & 0.167 & $\mathbf{0}$ & 0.333 \\
\hline Q18 & & 1 & $\mathbf{0}$ & $\mathbf{0}$ & 0.2 \\
\hline Q21 & & & 1 & $\mathbf{0}$ & 0.5 \\
\hline Q22 & & & & $\mathbf{0}$ & 1 \\
\hline Q29 & & & & & 1 \\
\hline
\end{tabular}

The dendrogram obtained from protein profiles grouped the five samples into two major clusters A \& B (Figure 3) containing one sample in cluster A (Q22 ). Four samples (Q18,Giza1,Q29 and Q21) in cluster
B. Cluster B was sub-divided into two sub-clusters B1\&B2. Sub cluster B1 consisted of two samples (Q18 and Giza1). Sub cluster B2 consisted of two samples(Q29 and Q21).

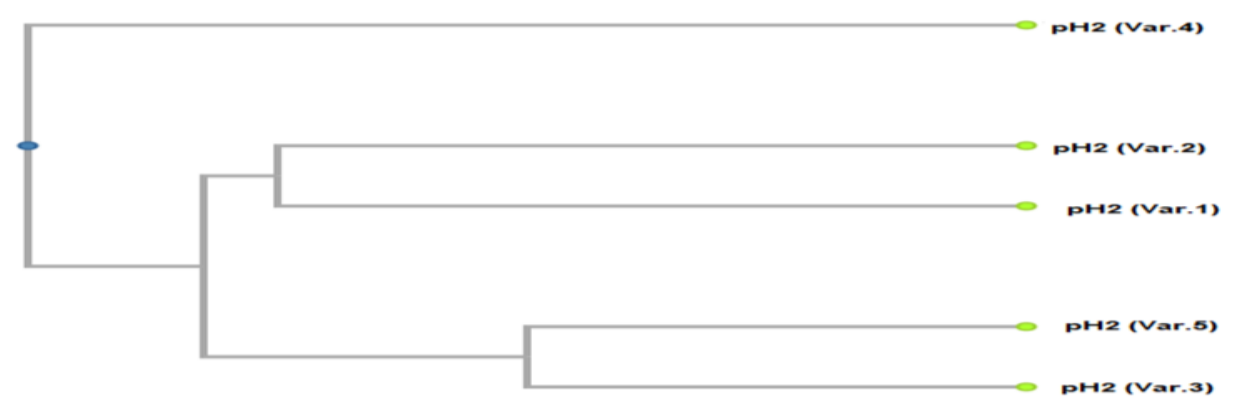

Fig 3. DendrogramShowing cluster analysis dissimilarity estimates from protein profiles of all genotype extracted in $\mathrm{PH} 2$ buffer.Var.1= Giza1, Var.2= Q18, Var.3=Q21, Var.4=Q22, Var.5=Q29.

The effect of adding Protein Extraction Buffer PH4

Total soluble proteins in all five samples (Giza1, Q18, Q21, Q22, and Q29) were resolved in 17 bands ranging from $(156.8 \mathrm{KDa}$ to $34.8 \mathrm{KDa})$. All five samples showed ten polymorphic bands at molecular weights(144.9,134.6,116.08,82.2,67.2,48.5,45.5,41.2, 39.7 and $34.8 \mathrm{kDa})$, and seven bands were monomorphic at molecular weights ((156.8 and72.7 $\mathrm{KDa}$ ) appeared only in genotype Giza1, 96.5KDa identified only in genotype Q29, 90.5KDa identified 
only in genotype Q22,53.4KDa identified only in genotypeQ21 and two bands $(\mathrm{MW}=62.4$ and 36.2) was identified only in one genotype Q18). Moreover, there were four bands not found only in the genotypeGiza1 theband (MW=116.08,67.2,48.5 and 34.8).

Table 4. Similarity analysis for the protein profiles of all genotype extracted in $\mathrm{PH} 4$ buffer.

\begin{tabular}{|c|c|c|c|c|c|}
\hline \multicolumn{6}{|c|}{ Similarity Matrix computed with Jaccard coefficient } \\
\hline & Giza1 & Q18 & Q21 & Q22 & Q29 \\
\hline Giza1 & 1 & 0.25 & 0.125 & 0.286 & 0.375 \\
\hline Q18 & & 1 & 0.625 & 0.444 & 0.5 \\
\hline Q21 & & & 1 & 0.5 & 0.4 \\
\hline Q22 & & & & 1 & 0.75 \\
\hline Q29 & & & & & 1 \\
\hline
\end{tabular}

The dendrogram obtained from protein profiles grouped the five samples into two major clusters A \& $\mathrm{B}$ (Figure 4) containing one sample in cluster A (Giza1 ). Four samples (Q21,Q18,Q29 and Q22) in cluster B. Cluster B was sub-divided into two subclusters B1\&B2. Sub cluster B1 consisted of two samples ( Q21 and Q18). Sub cluster B2 consisted of two samples(Q29 and Q22).

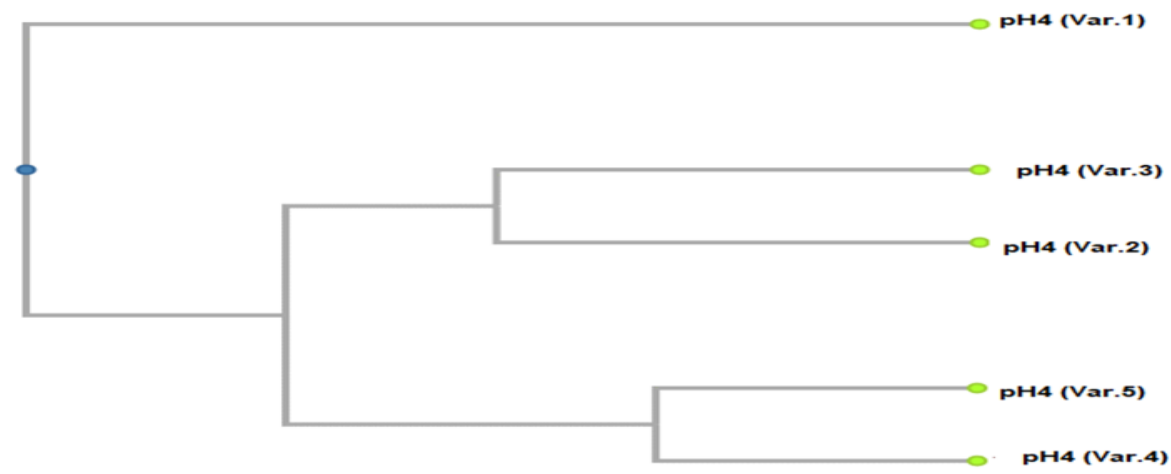

Fig 4. DendrogramShowing cluster analysis dissimilarity estimates from protein profiles of all genotype extracted in PH4 buffer.Var.1= Giza1, Var.2= Q18, Var.3=Q21, Var.4=Q22, Var.5=Q29.

The effect of adding Protein Extraction Buffer PH6.

Total soluble proteins in all five samples (Giza1, Q18, Q21, Q22, and Q29) were resolved in 13 bands ranging from $147.3 \mathrm{KDa}$ to $34.9 \mathrm{KDa}$. All five samples showed eleven polymorphic bands at molecular weights $(135.5$ ,117.9,71.6,67.02,64.3,48.6,46.005,43.5,39.9,36.4 and $34.9 \mathrm{kDa}$ ), and two bands were monomorphic at molecular weights $147.3 \mathrm{KDa}$ was identified only in genotype Q22 and 84.4KDa was identified only in genotype Q18. The three polymorphic bands at molecular weights $(117.9,48.6$ and $34.9 \mathrm{KDa})$ were appeared in all five genotypes. Moreover the band at $(\mathrm{MW}=64.005 \mathrm{KDa})$ was disappeared in only genotype Q18 but, the band at (MW=39.9KDa) was disappeared in only genotype Q21, also the band at $(\mathrm{MW}=36.4 \mathrm{KDa})$ was disappeared in only genotypeGiza1.

Table 5. Similarity analysis for the protein profiles of all genotype extracted in PH6 buffer.

\begin{tabular}{llllll}
\hline \multicolumn{7}{l}{ Similarity } & Matrix computed & with Jaccard coefficient & & \\
\hline Giza1 & Q18 & Q21 & Q22 & Q29 \\
\hline Q18 & 1 & 0.571 & 0.375 & 0.333 & 0.375 \\
\hline Q21 & 1 & 0.5 & 0.444 & 0.333 \\
\hline Q22 & & 1 & 0.625 & 0.714 \\
\hline Q29 & & & 1 & 0.625 \\
\hline
\end{tabular}

The dendrogram obtained from protein profiles grouped the five samples into two major clusters A \& B (Figure 5) containing two samples in cluster A (Giza1 and Q18). Three samples (Q22,Q29 and Q21) in cluster B. Cluster B was sub-divided into two subclusters B1\&B2. Sub cluster B1 consisted of the sample Q22. Sub cluster B2 consisted of two samples(Q29 and Q21). 


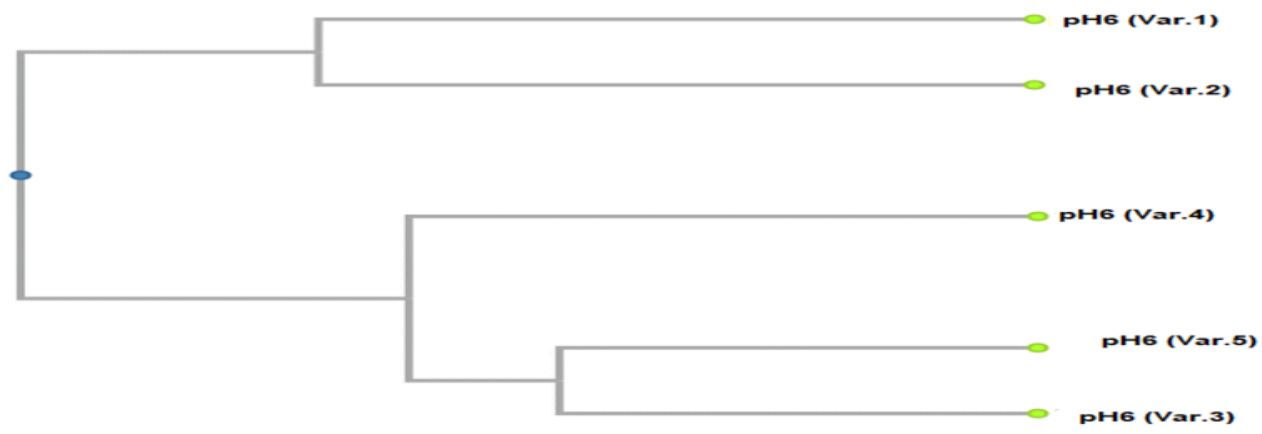

Fig5. DendrogramShowing cluster analysis dissimilarity estimates from protein profiles of all genotype extracted in PH6 buffer.Var.1= Giza1, Var.2= Q18, Var.3=Q21, Var.4=Q22, Var.5=Q29.

\section{Conclusion}

we can conclude that the quinoa protein is a promising nutritive source and candidate for using as food supplement and functional food but still needs more advanced research to improve its functional properties to be suitable for using in food processing. Quinoa is a source of many nutrients like protein (which contained essential amino acids), fibers, fats, and carbohydrates. It might consume as a part of a balanced meal with many other food types to obtain overall good nutrition. The optimum conditions for preparing protein isolate from quinoa seeds were noted in two steps: (a) protein extraction at alkaline $\mathrm{pH}$ value with stirring for $120 \mathrm{~min}$ and adding $0.5 \mathrm{M}$ $\mathrm{NaCl}$ and (b) isoelectric point precipitation at $\mathrm{pH}$ value. The protein profile on SDS-PAGE gel showed a high solubility at alkaline $\mathrm{pH}$ values (4).

\section{Acknowledgments}

Authors are thankful to the Crop Intensification Research Department in Agricultural Research Center, Cairo, Egypt

for obtained Quinoa seeds and, also they are thankful to the Agriculture Research Laboratories Park in Faculty of Agriculture at Benha University, Cairo, Egypt for providing the chemicals and facilities of this research work.

\section{Reference}

Ahamed NT, Singhal RS, Kulkarni PR, Kale DD, Pal M (1996b) Studies on Chenopodium quinoa and Amaranthuspaniculatas starch as biodegradable fillers in LDPE films.CarbohydrPolym 31:157-160

Abugoch, L.E., Romero, N., Tapia, C.A., Silva, J., Rivera, M., 2008. Study of some physicochemical and functional properties of quinoa(Chenopodium quinoa Willd) protein isolates. J. Agric. Food Chem. 56 (12), 4745-4750.
Bhargava A, Srivastava S (2013) Quinoa botany, production and uses. CAB International, Oxfordshire

Chauhan GS, Eskin NAM, Tkachuk R (1992) Nutrients and antinutrients in quinoa seeds. CrealChem 69:85-88

Elsohaimy, S.A. ,Refaay, T.M. , Zaytoun, M.A.M.,2015. Physicochemical and functional properties of quinoa protein isolate Annals of Agricultural Science 60(2), 297305.

Escuredo O, Inmaculada GMM, Moncada GW, Fischer S, Hierro JMH (2014) Amino acid profile of the quinoa (Chenopodium quinoa Willd.) using near infrared spectroscopy and chemometric techniques. J. Cereal Sci (in press)

Food and Agriculture Organization (FAO), 1985. Food and Agriculture Organization of the United States/World Health Organization/United Nations University, Energy and Protein Requirements Report of a joint FAO/WHO/UNU meeting. World Health Organization, Geneva.

Food and Agriculture Organization (FAO), 1998. Underutilized Andean Food Crops. Rome.

Food and Agriculture Organization (FAO), 2014. Assessment of the international year of quinoa 2013. Hundred and fortyninth session. CL 149/10. Rome, Italy.

Fuentes F, Bazile D, Bhargava A, Martinez EA (2012) Implications of farmers' seed exchanges for on-farm conservation of quinoa, as revealed by its genetic diversity in Chile. J AgricSci 150:702-716

Giusti L (1970) El generoChenopodium en Argentina 1: Numeros de cromosomas.Darwiniana 16:98-105

Jacobsen, S.E., Mujica, A., Jensen, C.R., 2003. The resistance of quinoa (ChenopodiumquinoaWilld.) to adverse abiotic factors. Food Rev. Int. 19, 99-109.

Lindeboom N (2005) Studies on the characterization, biosynthesis and isolation of starch and protein from quinoa (Chenopodium quinoa Willd.), University of askatchewan Degree of Doctor

Maughan PJ, Bonofacio A, Jellen EN, Stevens MR, Coleman CE, Ricks M, Mason SL, Jarvis DE, Gardunia BW, Fairbanks DJ (2004) A genetic linkage map of quinoa (Chenopodium quinoa) base on AFLP, RAPD and SSR markers. TheorAppl Genet 109:118-1195

Stikic R, Glamoclija D, Demin M, Vucelic-Radivic B, Jovanovic Z, Milokovic-Opsenica D et al (2012) Agronomical and nutritional evaluation of quinoa seeds (Chenopodium quinoa Willd.) as an ingredient in bread formulations. J Cereal Sci 55:132-138 
